\title{
DROUGHT TOLERANCE IN RECOMBINANT CHROMOSOME SUBSTITUTION LINES (RCSLs) DERIVED FROM THE CROSS Hordeum vulgare subsp. spontaneum (Caesarea 26-24) $\times$ Hordeum vulgare subsp. vulgare CV. HARRINGTON
}

\author{
Tolerancia a sequía en líneas recombinantes con sustitución de cromosomas \\ (RCSLs) obtenidas de la cruza Hordeum vulgare subsp. spontaneum \\ (Caesarea 26-24) x Hordeum vulgare subsp. vulgare cv. Harrington
}

\author{
Luis Inostroza ${ }^{1}$, Alejandro del Pozo ${ }^{2}$, Iván Matus $^{1}$ and Patrick Hayes ${ }^{3}$
}

\begin{abstract}
A B S T R A C T
Grain yield (GY) and drought tolerance of recombinant chromosome substitution lines (RCSLs) derived from the cross between Hordeum vulgare L. subsp. spontaneum (K. Koch) Thell. and H. vulgare L. subsp. vulgare $\mathrm{cv}$. Harrington, were studied in two contrasting environments, one with water stress (WWS) and the other with no water stress (NWS), during three growing seasons, 2004-2005, 2005-2006 and 2006-2007. In the first season 80 RCSLs were sowed and in the following a selection of 13 RCSLs. An $\alpha$-lattice design was used in all the experiments. With the data of GY obtained in sites WWS and NWS it was calculated the drought sensitivity index (DSI). During 2004-2005 growing season GY varied greatly among locations, reflecting differences in water availability. The average GY of the 80 RCSLs was 4.4 and $8.0 \mathrm{Mg} \mathrm{ha}^{-1}$ in sites WWS and NWS, respectively. The DSI varied between genotypes from 0.24 to 1.53 . Furthermore, the DSI was negative and significantly correlated with the grain yield obtained in the WWS site and allowed to select a group of genotypes tolerant and other sensitive to drought. The group of drought tolerant genotypes yielded in WWS 18,12 and $17 \%$ more than the sensitive ones, in 2004-2005, 2005-2006 and 2006-2007 seasons, respectively.
\end{abstract}

Key words: barley, drought sensitivity index, grain yield water stress, genotype.

\author{
R E S U M E N
}

\begin{abstract}
Se estudió el rendimiento de grano (GY) y la tolerancia a la sequía de líneas recombinantes con substitución de cromosomas (RCSLs), provenientes de la cruza entre Hordeum vulgare L. subsp. spontaneum (K. Koch) Thell. y H. vulgare L. subsp. vulgare, en dos ambientes contrastantes, uno con estrés hídrico (WWS) y otro sin estrés hídrico (NWS), durante tres temporadas de crecimiento, 2004-2005, 2005-2006 y 2006-2007. En la primera temporada se establecieron 80 RCSLs y en las siguientes se evaluó una selección de 13 RCSLs. Se utilizó un diseño $\alpha$-latice en todos los experimentos. Con los datos de GY obtenidos en los sitios WWS y NWS se calculó el índice de sensibilidad a la sequía (DSI). Durante la temporada 20042005, el GY varió ampliamente entre localidades, reflejando las diferencias en la disponibilidad de agua. El GY promedio de las 80 RCSLs fue 4,4 y $8,0 \mathrm{Mg} \mathrm{ha}^{-1}$ en los sitios WWS y NWS, respectivamente. El DSI varió ampliamente entre genotipos, desde 0,24 hasta 1,53 . Además, el DSI se correlacionó negativa y significativamente con el rendimiento de grano en el ambiente WWS y permitió seleccionar un grupo de genotipos tolerantes y otro sensibles a la sequía. El grupo de genotipos tolerantes a sequía mostró en el sitio WWS un rendimiento de grano promedio de 18, 12 y $7 \%$ superior al de los no tolerantes, en las temporadas 2004-2005, 2005-2006 y 2006-2007, respectivamente.
\end{abstract}

Palabras clave: cebada, índice de sensibilidad a la sequía, rendimiento estrés hídrico, genotipos.

\footnotetext{
${ }^{1}$ Instituto de Investigaciones Agropecuarias, Centro Regional de Investigación Quilamapu, Casilla 426, Chillán, Chile.

${ }^{2}$ Universidad de Talca, Facultad de Ciencias Agrarias, Casilla 747, Talca, Chile. E-mail: adelpozo@utalca.cl *Author for correspondence.

${ }^{3}$ Oregon State University, Department of Crop and Soil, Corvallis, Oregon, 97331-3002, USA.

Received: 8 August 2006. Accepted: 20 September 2006.
} 


\section{INTRODUCTION}

One of the main purposes of genetic improvement in plants is developing genotypes with high yield potential and with the ability to maintain grain yield in different environments. This is particularly true in certain Mediterranean environments, where grain yield (GY) varies among sites and growing seasons, as a consequence of variation in distribution and amount of rain (Acevedo et al., 1991). On this scenario, agronomists, breeders and physiologists have aimed their efforts to develop drought tolerant genotypes.

Drought can reduce significantly GY, and restricts latitudes and soils where economically important species can be grown. Development of drought tolerant genotypes and with higher efficiency in use of water is of global interest, due to continuous growth in global population and decrease of water resources destined to agriculture (Nguyen, 1999). Additionally, it will allow world food production increase, and will provide more safety to agriculture in marginal environments, which usually show high risks due to drought and high temperature stress (Baum et al, 2003).

Cereal genetic improvement in Mediterranean environments has been mainly based on empirical selection of GY perse. However, this methodology is not optimum since GY is a character with low heritability and high interaction genotype $\times$ environment $(\mathrm{G} \times \mathrm{E})$ (Richards et al., 2002). It is argued that an analytical or indirect selection methodology, based on comprehension of crops at physiological and molecular level, may help identifying key features that limit GY. Such methodologies may complement conventional breeding programs (empirical) and thus accelerate improvement of GY (Reynolds et al., 1999; 2005; Araus et al., 2002; Richards et al., 2002).

Barley (Hordeum vulgare L. subsp. vulgare) (hereafter vulgare) is considered a model species for physiological and genetic surveys due to several reasons: (1) it is an important crop worldwide, especially in Mediterranean regions; (2) it shows high degree of self-pollination and its crossbreeding is compatible with species within primary pool of genes; (3) it is an annual species with a short lifecycle; (4) it is diploid with only seven pairs of chromosomes; (5) it shows a wide range of physiological, morphological and genetic diversity; (6) there is a wide genetic reserve; and (7) there are well defined genetic maps (Forster et al., 2000).

In barley genetic improvement, hybridization of parents look for desirable agronomic traits, and afterward the best recombinants are selected among offsprings (Thomas, 2002). In most cases collections of germplasm have been used as source of genetic diversity, however, the level of diversity in many breeding programs is limited (Matus y Hayes, 2002).

Studies on genetic diversity in wild barley (Hordeum vulgare L. subsp. spontaneum (K. Koch) Thell.) (hereafter spontaneum) show that the cultivated barley presents just part of the variation shown by its wild ancestor. Molecular studies indicate that only $40 \%$ of alleles found in wild barley are present in cultivated barley genotypes (Ellis et al., 2000). Furthermore, the cultivated barley (vulgare) and its wild ancestor differ in some agronomic important traits, such as seminal root, floral structure, tolerance to salinity, grain size, protein content, earliness, production of biomass and grain, plant height in drought conditions and tolerance to drought (Baum et al., 2003). Therefore, wild progenitor of the cultivated barley can contribute with useful alleles for many traits that have been lost during domestication process (Ellis et al., 2000).

Although crossing these two species (spontaneum and vulgare) is easy to perform and they are very fertile, introgression of genes is a difficult task due to the fact that many unacceptable agronomic traits are present in spontaneum, such as brittle rachis, low kernel weight, asynchronous tillering and rough awns (Baum et al., 2003). As a consequence, genetic progress rate will depend on the occurrence of favorable variation for development and growth and on the availability of methodologies conferring precision in transferring genes and selection (Ellis et al., 2000).

In searching genetic variability in barley, Matus et al. (2003) developed a population of Recombinant Chromosome Substitution Lines (RCSLs) by crossing spontaneum (accession Caesarea 26-24, from Israel) and vulgare cv. Harrington (North American malting quality standard). In a preliminary assessment of RCSLs, it was noted that spontaneum ancestral genome introgression, in many cases caused loss of acceptable phenotype in the cultivated 
progenitor. However, in some cases spontaneum genome was a source of favorable alleles for some agronomic important traits and with malting quality (Matus et al., 2003).

RCSLs represent a useful source of genetic diversity possible to be used as a model for physiological and genetic research. Additionally, accession Caesarea 26-24 was collected in an arid and saline location in Israel, which suggests that genome segment introgression of this accession on cv. Harrington may have effects in characteristics conferring adaptability or tolerance to abiotic stress, particularly to drought.

The purpose of this research was assessing grain yield and drought tolerance of these barley genotypes in Mediterranean environments.

\section{MATERIALS AND METHODS}

\section{Vegetal genetic resource}

Recombinant chromosome substitution lines (RCSLs) were derived from the cross between spontaneum accession Caesarea 26-24 and vulgare cv. Harrington. Spontaneum was the donor and vulgare the recurrent parent. The lines were obtained by two backcrosses to the recurrent parent and six generations of self pollination (Matus et al., 2003). Additionally, two checks were included, the recurrent parent (Harrington) with malting quality and high grain yield potential, and the cv. Baronesse with feed ability.

\section{Field trials}

\section{4-2005 growing season}

Eighty barley RCSLs were assessed in two Mediterranean environments in Chile, Cauquenes (35 $58^{\prime}$ 'South; $72^{\circ} 17^{\prime}$ West; 177 m.a.s.1.) under dryland condition and a precipitation of $414 \mathrm{~mm}$ during the growing season, and Santa Rosa (36 $32^{\circ}$ ' South; $71^{\circ} 55^{\prime}$ West; 220 m.a.s.1.), under irrigated condition. Cauquenes was the site where the crop remained under water stress (WWS) during the grain filling period and Santa Rosa was the site with no water stress (NWS). In Cauquenes, soil texture is sandy clay loam (Entisol; Palexeralfs) and in Santa Rosa it is clay loam (Andisol; Dystrandepts).

The sowing date was 27 May and 30 August 2004, in Cauquenes and Santa Rosa, respectively. The soil was prepared with disk plough and disk harrow.
Base fertilization of $260 \mathrm{~kg} \mathrm{ha}^{-1}$ of diammonium phosphate was applied $\left(46 \% \mathrm{P}_{2} \mathrm{O}_{5}\right.$ and $18 \%$ of $\left.\mathrm{N}\right)$, $90 \mathrm{~kg} \mathrm{ha}^{-1}$ of potassium chloride $\left(60 \%\right.$ of $\left.\mathrm{K}_{2} \mathrm{O}\right), 200$ $\mathrm{kg} \mathrm{ha}^{-1}$ of sulpomag $\left(22 \% \mathrm{~K}_{2} \mathrm{O}, 18 \% \mathrm{MgO}\right.$ and $22 \%$ de S), $10 \mathrm{~kg} \mathrm{ha}^{-1}$ of boronatrocalcite (11\% of B) and $3 \mathrm{~kg} \mathrm{ha}^{-1}$ de zinc sulphate ( $35 \%$ of $\mathrm{Zn}$ ). Fertilizers were applied on broadcasting and incorporated in the soil with a rotary tiller. The seeds of each genotype were sowed in three $1 \mathrm{~m}$-long rows, separated $0.2 \mathrm{~m}$, at the rate of $120 \mathrm{~kg} \mathrm{ha}^{-1}$. At the Zadoks 21 (Zadoks et al., 1974), 80 units of nitrogen $\mathrm{ha}^{-1}$ were applied to the soil and for weed control a solution of MCPA $750 \mathrm{~g}$ i.a. ha- $\mathrm{ha}^{-1}+$ metsulfuronmetil 8 g i.a. ha ${ }^{-1}$.

\section{5-2006 and 2006-2007 seasons}

With the results of season 2004-2005, 13 RCSLs were selected. These were established in Cauquenes (WWS site) on 2 June 2005 and 30 May 2006, and in Santa Rosa (NWS site) on 7 September 2005 and 21 August 2006. The seeds of each genotype were sowed in six rows $2 \mathrm{~m}$-long, separated at $0.2 \mathrm{~m}$. Seed rate used in both sites was $120 \mathrm{~kg} \mathrm{ha}^{-1}$. Soil preparation and agronomic practices were performed as during 2004-2005 season. Annual precipitation for WWS site was 614 and $608 \mathrm{~mm}$ during 20052006 and 2006-2007 seasons, respectively. For NWS site plots were irrigated twice during each growing season.

\section{Experimental design}

Experimental design used in all trials was an $\alpha$-latice. During 2004-2005 season two replicates and seven incomplete blocks per each replicate were established, with each block containing 12 lines. In each replicate, 84 lines were arranged (treatments) and total number of plots was $168(7 \times 12 \times 2=168)$. Two checks were used, cv. Harrington, the recurrent parent and Baronesse. Checks were sowed twice at each replication. During 2005-2006 season four replicates and three incomplete blocks per each replicate were established, with each block containing five lines. At each replicate 15 genotypes were arranged (13 RCSLs and the cv. Harrington and Baronesse).

\section{Evaluations}

During 2004-2005 season, grain yield (GY) was assessed by harvesting the whole plot in both sites. During 2005-2006 and 2006-2007 seasons, four central rows were harvested in Cauquenes, and three in Santa Rosa. With grain yield data, drought 
sensitivity index (DSI) was calculated according to Fisher and Maurer (1978): DSI $=\left[1-\left(\mathrm{Y}_{\mathrm{D}} / \mathrm{Y}_{\mathrm{p}}\right)\right] / \mathrm{D}$, where $Y_{D}$ is the grain yield obtained in the highest water stress site (Cauquenes), $\mathrm{Y}_{\mathrm{P}}$ is grain yield obtained in site without water stress (Santa Rosa), $\mathrm{D}$ is environmental stress intensity index. The latter is calculated as: $\mathrm{D}=1-\left(\mathrm{XY}_{\mathrm{D}} / \mathrm{XY}_{\mathrm{P}}\right)$, where $\mathrm{XY}_{\mathrm{D}}$ is the mean grain yield of all genotypes in stress site (Cauquenes) and $\mathrm{XY}_{\mathrm{p}}$ is the mean grain yield of all genotypes in site without stress (Santa Rosa).

The interaction genotype $\times$ environment $(\mathrm{G} \times \mathrm{E})$ of 13 RCSLs selected during season 2004-2005 was estimated according to Finlay and Wilkinson (1963), and was determined as the slope (b) of the regression between grain yield of each RCSL and mean yield of all genotypes in the same site (environmental index). For calculating of this index, GY data obtained in both sites (WWS and NWS) and in the three growing seasons (2004-2005, 2005-2006 and 2006-2007) were used. Deviation of regression proposed by Finlay and Wilkinson (1963), estimated from mean squares, was used as an index of stability of GY (Calderini and Dreccer 2002; Kraakman et al., 2004).

\section{Statistical analysis}

The data was analyzed through ANOVA and the PROC MIXED model was used in SAS (SAS Institute, 1999), where the RCSLs were considered as fixed effect, while blocks and incomplete blocks within each repetition as random effects. Least Square Means were calculated for the RCSLs and significance of the difference from recurrent parent (Harrington) was obtained with diff command in SAS.

\section{RESULTS AND DISCUSSION}

\section{Grain yield season 2004-2005}

Grain yield (GY) of the 80 RCSLs varied widely among sites, reflecting the difference in water availability during the entire growing season. Average GY of the 80 RCSLs was 4.4 (range 2.56.0) in WWS site and 8.0 (range 4.8-10.3) $\mathrm{Mg} \mathrm{ha}^{-1}$ in NWS site (Figure 1). In both locations, the GY varied significantly among genotype $(\mathrm{P}<0.05)$. Additionally, in both sites, the genotype with lowest GY was RCSL-89 and with highest GY was RCSL-82. Cv. Baronesse had a GY significantly $(\mathrm{P}<0.05)$ higher than Harrington's only in NWS site (Table 1).
In WWS site, none of the RCSLs showed a GY higher than recurrent parent, whereas in NWS site, at least three genotypes showed a GY significantly $(\mathrm{P}<0.05)$ higher than $\mathrm{cv}$. Harrington (Table 1). This was an important finding because gene introgression from spontaneum to vulgare is an extended and difficult process, since spontaneum has many undesirable agronomic features, as mentioned in the introducction. With the information available up to date, it is not possible to infer that the increase in GY of these RCSLs is due to introgression of new alleles coming from the wild progenitor. However, RCSLs are characterized with 47 molecular markers (micro satellites) and, by
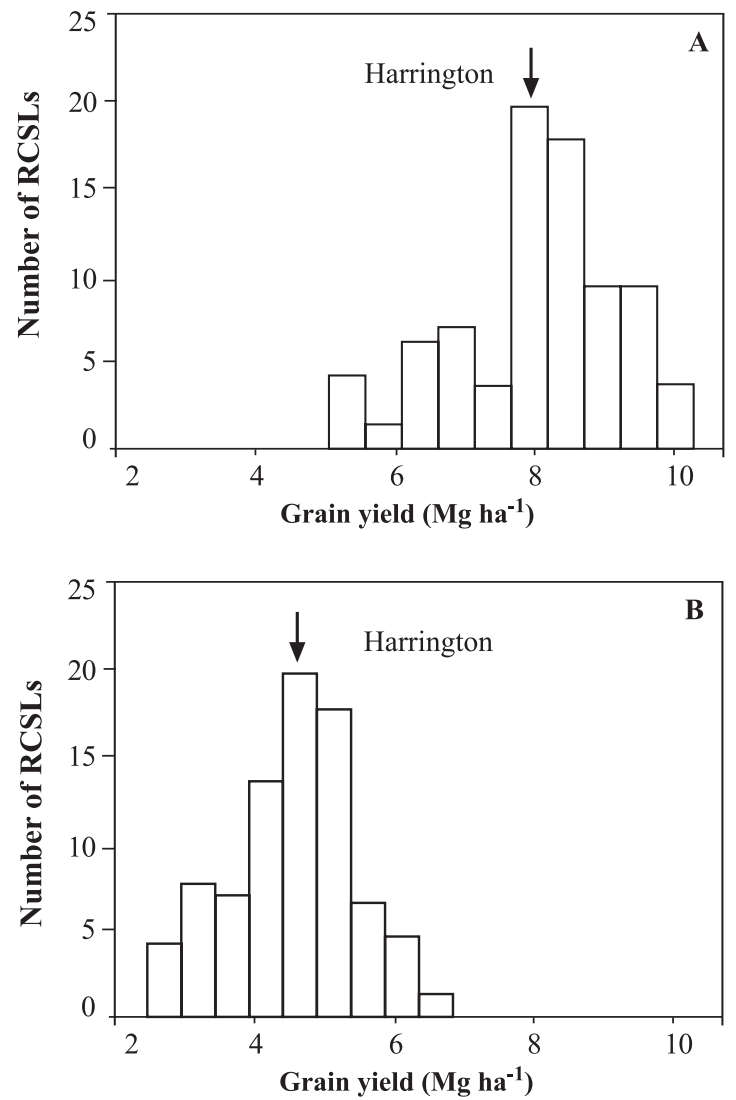

Figure 1. Frequency distribution of grain yield of 80 RCSLs evaluated in two contrasting environments. A: Santa Rosa (no water stress) and B: Cauquenes (with water stress), during 2004-2005 growing season.

Figura 1. Distribución de frecuencias de rendimiento de grano de 80 RCSLs evaluada en dos ambientes contrastantes. A: Santa Rosa (sin estrés hídrico) y B: Cauquenes (con estrés hídrico), durante la temporada 2004-2005. 
Table 1. Grain yield (GY; $\mathrm{Mg} \mathrm{ha}^{-1}$ ) of the five genotypes with the highest and lowest yield in two sites with contrasting water availability. Cauquenes (with water stress) and Santa Rosa (no water stress), in 2004-2005 growing season.

Cuadro 1. Rendimiento de grano (GY; $\mathrm{Mg} \mathrm{ha}^{-1}$ ) de los cinco genotipos de mayor y menor rendimiento en dos localidades que presentan disponibilidad de agua contrastante. Cauquenes (con estrés hídrico) y Santa Rosa (sin estrés hídrico), en la temporada 2004-2005.

\begin{tabular}{|c|c|c|c|}
\hline \multicolumn{2}{|c|}{ Cauquenes } & \multicolumn{2}{|c|}{ Santa Rosa } \\
\hline RCSLs & GY & RCSLs & GY \\
\hline \multicolumn{4}{|c|}{ Higher grain yield RCSLs } \\
\hline 117 & 5.7 & 100 & 9.6 \\
\hline 82 & 5.8 & 116 & 9.7 \\
\hline 4 & 5.9 & 82 & $9.8 *$ \\
\hline 90 & 6.0 & 103 & $10.1 * *$ \\
\hline 95 & 6.0 & 124 & $10.3 * *$ \\
\hline \multicolumn{4}{|c|}{ Lower grain yield RCSLs } \\
\hline 89 & $2.5 * *$ & 89 & $4.8 * *$ \\
\hline 106 & $2.7 *$ & 29 & $5.1 * *$ \\
\hline 99 & $2.8 *$ & 53 & $5.2 * *$ \\
\hline 24 & $2.9 *$ & 132 & $5.8^{*}$ \\
\hline 139 & $2.9 *$ & 91 & $5.9 *$ \\
\hline \multicolumn{4}{|c|}{ Controls (recurrent parent and variety) } \\
\hline Baronesse & 6.5 & Baronesse & $9.8 * *$ \\
\hline Harrington & 5.1 & Harrington & 7.9 \\
\hline
\end{tabular}

*, ** Difference from recurrent parent (Harrington) statistically significant with $\mathrm{P}<0.05$ and $\mathrm{P}<0.01$, respectively.

genetic research, it is being elucidated the effect of introgression on the expression of phenotypical characters of agronomic interest.

Talamé et al. (2004) assessed the GY in 123 lines double haploid of a population $\mathrm{BC}_{1} \mathrm{~F}_{2}$ obtained from the backcross of cv. Barke (European barley cultivar) and HOR 11508 (accession of wild barley), in three sites under Mediterranean climate conditions. GY of these 123 lines double haploid varied widely from site to site (0.9-2.9 $\left.\mathrm{Mg} \mathrm{ha}^{-1}\right)$ and the highest grain yield (5.4 $\left.\mathrm{Mg} \mathrm{ha}^{-1}\right)$ was obtained in the site of higher water availability. In general, in this study, RCSLs showed higher GY than that of Talamé et al. (2004) double haploid lines, probably due to the fact that the two sites presented higher water availability.

By molecular and genetic research, Talamé et al. (2004) found that introgression of alleles from barley wild ancestor (spontaneum) increased by $17 \%$ the
GY of barley. In a similar study, using 136 individuals from a $\mathrm{BC}_{2} \mathrm{~F}_{2}$ population derived from the backcross of cv. Apex (North American cultivar) and ISR101-23 (accession of wild barley), Pillen et al. (2003) found that the genotype of wild ancestor achieved to increase by $7.7 \%$ the GY of barley.

\section{Selection of drought tolerant genotypes}

Drought tolerance was assessed in the 80 RCSLs through the drought sensitivity index (DSI) proposed by Fischer and Maurer (1978). During 2004-2005 season, drought intensity (D) was 0.45 . The DSI varied widely among genotypes, from 0.24 (RCSL95) to 1.53 (RCSL-24) (Figure 2); Harrington and $\mathrm{cv}$. Baronesse had values of 0.76 and 0.80 , respectively. Since lower value of DSI means higher tolerance to drought, it can be inferred that RCSL95 was the most tolerant genotype, while RCSL-24 was the most sensitive to drought. The DSI was correlated negatively and significantly to grain yield in site WWS (Cauquenes; Figure 3), which agree with the results from other studies (Ceccarelli, 1987; Acevedo et al., 1991; Shakhatreh et al., 2001).

The DSI was used to select two contrasting groups of genotypes (Table 2). One group of genotypes sensitive to drought, which showed a high value of DSI $(>1)$ and grain yield equal or lower than recurrent parent in site WWS, and another group of genotypes tolerant to drought, which showed a low value of DSI and high grain yield in site WWS.

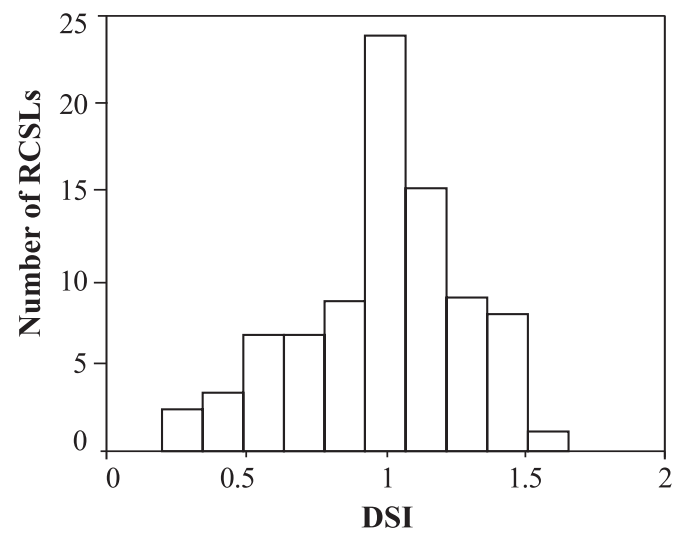

Figure 2. Frequency distribution of the drought sensitivity index (DSI) of 80 RCSLs evaluated in two contrasting environments in Chile.

Figura 2. Distribución de frecuencias del índice de sensibilidad a la sequía (DSI) de 80 RCSLs evaluado en dos ambientes contrastantes en Chile. 
Table 2. Drought sensitivity index (DSI) and the slope (b) and mean square (MS) obtained from Finlay and Wilkinson regression, based on grain yield of 13 RCSLs grown in environments with and without water stress, during three growing seasons (2004-2005, 2005-2006 and 2006-2007).

Cuadro 2. Índice de sensibilidad a la sequía (DSI) y pendiente (b) y cuadrados medios (MS) de la regresión de Finlay y Wilkinson basados en el rendimiento de granos de 13 RCSLs establecidas en ambientes con y sin estrés hídrico, durante tres temporadas de crecimiento (2004-2005, 2005-2006 y 2006-2007).

\begin{tabular}{lccc}
\hline RCSLs & DSI 2004 & b & MS \\
\hline $\begin{array}{l}\text { Checks } \\
\text { Baronesse }\end{array}$ & 0.76 & 1.3 & 46.1 \\
Harrington & 0.80 & 1.1 & 32.2 \\
Sensitives & & & \\
89 & 1.10 & 0.6 & 10.3 \\
103 & 1.25 & 1.2 & 41.9 \\
116 & 1.05 & 1.1 & 33.9 \\
124 & 1.20 & 1.3 & 49.3 \\
140 & 1.10 & 1.1 & 34.4 \\
Tolerants & & & \\
5 & 0.38 & 0.9 & 21.0 \\
8 & 0.46 & 0.8 & 16.0 \\
41 & 0.85 & 1.0 & 26.3 \\
42 & 0.95 & 1.0 & 31.7 \\
45 & 0.76 & 1.0 & 28.4 \\
95 & 0.24 & 1.0 & 26.2 \\
102 & 0.70 & 1.0 & 28.5 \\
130 & 0.50 & 0.8 & 20.3 \\
\hline
\end{tabular}

Agronomic performance of selected genotypes GY in site WWS was on average 38, 78 and $47 \%$ lower than in site NWS in seasons 2004-2005, 2005-2006 and 2006-2007, respectively (Table 3). In 2005-2006 season, GY was lower due to root diseases in Cauquenes and lack of water from the emergency to beginning of tillering in Santa Rosa. Correlations between GY in sites WWS and NWS were not significant $(\mathrm{P}>0.05)$ within each season, but were significant when taking the three years altogether $(\mathrm{r}=0.78 ; \mathrm{p}<0.00001 ; \mathrm{N}=44)$. This shows that the genotypes have differential behavior in both environments, but in favorable years, grain yield increases in both environments.

The group of genotypes tolerant to drought showed in Cauquenes an average GY of 18, 12 and 7\% higher than that of no tolerant ones, in seasons 2004-2005, 2005-2006 and 2006-2007, respectively; lines RCSL-41 and RCSL-8 showed an outstanding performance in seasons 2005-2006 and 2006-2007 overcoming the GY of the recurrent parent cv. Harrington (Table 3). Among sensitive ones, the line RCSL-89 showed the lowest GY both in Cauquenes and in Santa Rosa. It is worth mentioning that lines classified as tolerant to drought in site NWS had GY 24 and 21\% higher than sensitive ones in seasons 2004-2005 and 2005-2006, respectively.

Interaction $\mathrm{G} \times \mathrm{E}$ was assessed through methodology proposed by Finlay and Wilkinson (1963). This methodology assumes a direct measure of the answer of a genotype to changes in growing environment (favorable vs. unfavorable condition). Finlay and Wilkinson (1963) found several patterns of interaction $\mathrm{G} \times \mathrm{E}$ in their experiments, and concluded that for selection purposes the best pattern is choosing genotypes presenting high average GY and regression coefficient (b) equal to one. In Figure 4 it is shown an example of three contrasting genotypes in the $\mathrm{G} \times \mathrm{E}$ interaction. The $\mathrm{cv}$. Harrington showed a regression coefficient (b) equal to one, which means that this variety has high capacity of response to the environment; as growing conditions get better, cv. Harrington increases GY. RCSL-124 showed a regression coefficient higher than one (1.3), which means that this line shows even higher response capacity in favorable environments. On the other hand, RCSL- 8 showed $\mathrm{a} b$ value lower than $1(0.8)$ which indicated that this line presents a low yield response to favorable environment.

Finlay and Wilkinson (1963) mean square (MS) of regression is an estimator of GY stability (Calderini y Dreccer, 2002; Kraakman et al., 2004). GY stability varied from 10.3 (RCSL-89) to 49.3 (RCSL-124) (Table 2) For high grain yield environments, Calderini and Dreccer (2002) recommend selecting genotypes showing high average GY, high b value and low MS value. Whereas, for low grain yield environments, it is recommended selecting genotypes showing high average GY, low b value and low MS value. RCSL-5 and RCSL-8, selected as genotypes tolerant to drought, presented the lower $\mathrm{b}$ and MS values, so they are genotypes that yield less in unfavorable conditions, but its potential grain yield is low when they are grown in favorable environments. RCSL-89 also presented low b and MS value, but presented low GY in all environments. 


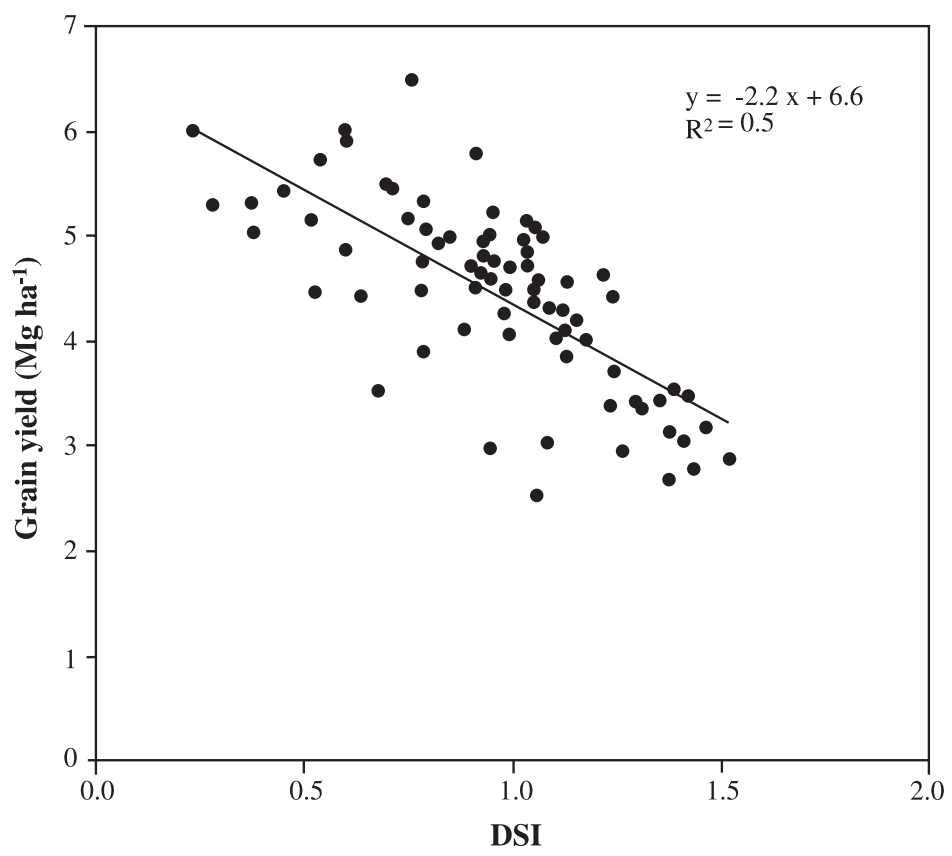

Figure 3. Relationship between grain yield of 80 RCSLs and drought sensitivity index (DSI), determined in the lower yield and drier environments (Cauquenes) in 2004-2005.

Figura 3. Relación entre el rendimiento de grano de las 80 RCSLs y el índice de sensibilidad a la sequía (DSI), determinada en el ambiente de menor rendimiento de grano y mayor estrés hídrico (Cauquenes) en 2004-2005.

Table 3. Grain yield (Mg ha ${ }^{-1}$ ) of 13 RCSLs differing in their drought tolerance (sensitive and tolerant), in two Mediterranean environments of Chile, Cauquenes (with water stress) and Santa Rosa (no water stress), during three growing seasons (2004-2005, 2005-2006 and 2006-2007).

Cuadro 3. Rendimiento de grano $\left(\mathrm{Mg} \mathrm{ha}^{-1}\right)$ de $13 \mathrm{RCSLs}$ que difieren en tolerancia a sequía (sensible y tolerantes), obtenido en dos ambientes mediterráneos de Chile, Cauquenes (con estrés hídrico) y Santa Rosa (sin estrés hídrico), durante tres temporadas de crecimiento (2004-2005, 2005-2006 y 2006-2007).

\begin{tabular}{|c|c|c|c|c|c|c|}
\hline \multirow[t]{2}{*}{ RCSLs } & \multicolumn{3}{|c|}{ Cauquenes } & \multicolumn{3}{|c|}{ Santa Rosa } \\
\hline & 2004-2005 & 2005-2006 & 2006-2007 & 2004-2005 & 2005-2006 & 2006-2007 \\
\hline \multicolumn{7}{|l|}{ Controls } \\
\hline Baronesse & $6.5^{*}$ & 0.8 & 2.7 & $9.8^{*}$ & $4.8^{* *}$ & 5.6 \\
\hline Harrington & 5.1 & 0.7 & 3.0 & 7.9 & 6.0 & 6.5 \\
\hline \multicolumn{7}{|l|}{ Sensitives } \\
\hline 89 & $2.5^{* *}$ & 0.5 & $2.1 * * *$ & $4.8 * *$ & $2.9 * *$ & $3.7 * * *$ \\
\hline 103 & 4.4 & 1.1 & 3.5 & $10.1 *$ & $4.9^{*}$ & 5.9 \\
\hline 116 & 5.1 & 1.2 & 3.3 & $9.7 *$ & $3.1 * *$ & $4.1 * * *$ \\
\hline 124 & 4.6 & 1.0 & 2.5 & $10.3 *$ & $3.9 * *$ & 6.2 \\
\hline 140 & 5.1 & $1.3^{*}$ & 3.8 & $9.6^{*}$ & $4.6^{* *}$ & 5.4 \\
\hline \multicolumn{7}{|l|}{ Tolerants } \\
\hline 5 & 5.3 & 1.0 & 2.8 & 6.4 & 5.4 & 6.5 \\
\hline 8 & 5.4 & $1.9 * *$ & 3.8 & 6.8 & 5.7 & 6.7 \\
\hline 41 & 5.0 & $1.4^{*}$ & $3.9^{*}$ & 8.1 & $5.0^{*}$ & 6.8 \\
\hline 42 & 5.0 & $1.4^{*}$ & 3.4 & 8.8 & $4.9^{*}$ & 6.4 \\
\hline 45 & 5.2 & 1.2 & 3.3 & 7.8 & $5.2 *$ & 7.1 \\
\hline 95 & 6.0 & 0.5 & 2.5 & 6.7 & $4.9^{*}$ & 6.0 \\
\hline 102 & 5.5 & 0.9 & 3.6 & 8.0 & $5.2 *$ & 6.0 \\
\hline 130 & 5.1 & 1.0 & 2.9 & 6.7 & $4.4^{* *}$ & 5.6 \\
\hline
\end{tabular}

*, ** Difference from recurrent parent (Harrington) statistically significant with $\mathrm{P}<0.05$ and $\mathrm{P}<0.01$ respectively. 


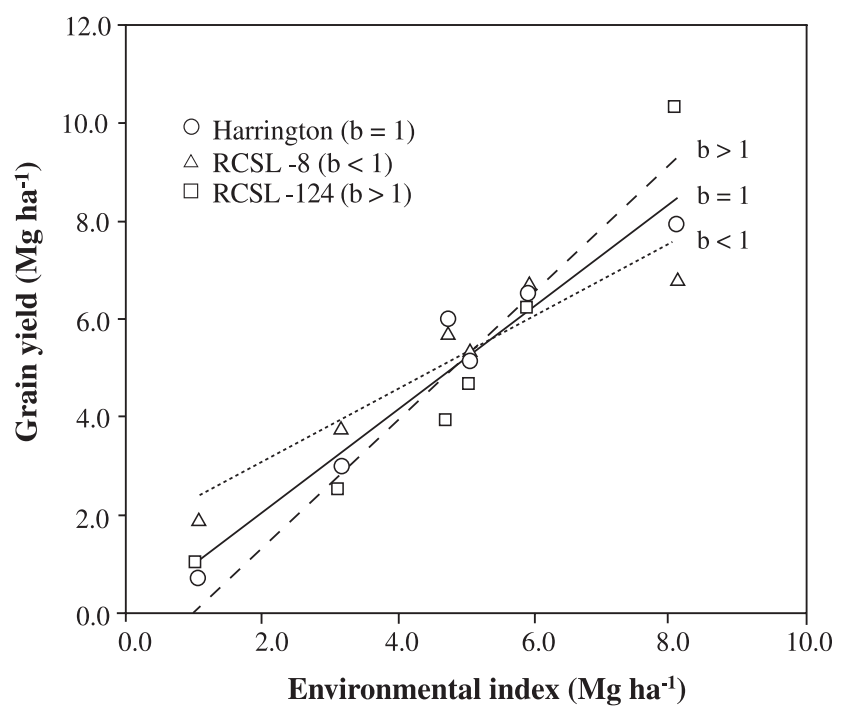

Figure 4. Yield adaptability evaluated as the relationship between grain yield and environmental index of two contrasting RCSLs (8 and 124) and the cv. Harrington. b is the regression coefficient.

Figura 4. Adaptabilidad del rendimiento evaluado como la relación entre el rendimiento de grano y el índice ambiental de dos RCSLs contrastantes $(8$ y 124) y el cv. Harrington. b es el coeficiente de regresión.

On the other hand, the group of RCSLs selected as tolerant to drought showed higher GY stability than the group of the sensitive ones, since mean of MS was $36 \%$ lower in the tolerant ones than in the sensitive ones (Table 2).

\section{CONCLUSIONS}

Under Mediterranean weather conditions, RCSLs differ widely in their agronomic performance, which was observed by the wide range of variation observed in GY among genotypes and environments.
Drought sensitivity index was a good parameter for selecting genotypes presenting higher grain yield under water stress conditions. Furthermore, RCSLs showed a wide genotypic variation for this character.

\section{ACKNOWL EDGEMENTS}

This work was supported by a grant from INIA and from FONDECYT (Projet $N^{\circ}$ 1060546). 


\section{LITERATURA CITADA}

Acevedo, E., P.Q. Craufurd, R.B. Austin, and P. PerezMarco. 1991. Traits associated with high yield in barley in low-rainfall environments. J. Agric. Sci. 116:23-36.

Araus, J.L., G.A. Slafer, M. Reynolds, and C. Royo. 2002. Plant breeding and drought in $\mathrm{C}_{3}$ cereals: What should we breed for? Ann. Bot. 89:925-940.

Baum, M., S. Grando, G. Backes, A. Jahoor, A. Sabbagh, and S. Ceccarelli. 2003. QTLs for agronomic traits in the Mediterranean environment identified in recombinant inbred lines of the cross 'Arta' $\mathrm{H}$. spontaneum 41-1. Theor. Appl. Genet. 107:12151225.

Calderini, D., and F. Dreccer. 2002. Choosing genotype, sowing date, and plant density for malting barley. p. 413-443. In G. Slafer, J. Molina, R. Savin, J. Araus, and I. Romagosa (eds.). Barley science. Recent advances from molecular biology to agronomy of yield and quality. Food Products Press, New York, USA.

Ceccarelli, S. 1987. Yield potential and drought tolerance of segregating populations of barley in contrasting environments. Euphytica 36:265-273.

Ellis, R., B. Foster, L. Handley, D. Gordon, J. Russell, and W. Powell. 2000. Wild barley: a source of genes for crop improvement in the 21st century? J. Exp. Bot. 51:9-17.

Finlay, K., and G. Wilkinson. 1963. The analysis of adaptation in a plant-breeding program. Aust. J. Agr. Res. 14:742-754.

Fischer, R., and R. Maurer. 1978. Drought resistance in spring wheat cultivars. I. Grain yield responses. Aust. J. Agric. Res. 29:897-905.

Forster, B., R. Ellis, W. Thomas, A. Newton, R. Tuberosa, D. This, et al. 2000. The development and application of molecular markers for abiotic stress tolerance in barley. J. Exp. Bot. 51:19-27.

Kraakman, A.T.W., R.E. Niks, P.M. Van den Berg, P. Stam, and F.A. Van Eeuwijk. 2004. Linkage disequilibrium mapping of yield and yield stability in modern spring barley cultivars. Genetics 168:435-446.

Matus, I., A. Corey, T. Filichkin, P. Hayes, M.I. Vales, J. Kling, et al. 2003. Development and characterization of recombinant chromosome substitution lines (RCSLs) using Hordeum vulgare subsp. spontaneum as a source of donor alleles in a Hordeum vulgare subsp. vulgare background. Genome 46:1010-1023.
Matus, I., and P.M. Hayes. 2002. Genetic diversity in three groups of barley germplasm assessed by simple sequence repeats. Genome 45:1095-1106.

Nguyen, H. 1999. Molecular dissection of drought resistance in crop plants: from traits to genes. p. 3640. In J.M. Ribaut and D. Poland (eds.). Molecular approaches for the genetic improvement of cereals for stable production in water-limited environments. CIMMYT, Mexico D.F.

Pillen, K., A. Zacharias, and J. Leon. 2003. Advanced backcross QTL analysis in barley (Hordeum vulgare L.). Theor. Appl. Genet. 107:340-352.

Reynolds, M.P., S. Rajaram, and K. Sayre. 1999. Physiological and genetics changes of irrigated wheat in the post-green revolution period and approaches for meeting projected global demand. Crop Sci. 39:1611-1621.

Reynolds, M.P., A. Mujeeb-Kazi, and M. Sawkins. 2005. Prospect for utilizing plant-adaptive mechanisms to improve wheat and other crops in drought-and salinity-prone environments. Ann. Appl. Biol. 146:239-259.

Richards, R.A., G. Rebetzke, A.G. Condon, and A.F.V. Herwaarden. 2002. Breeding opportunities for increasing the efficiency of water use and crop yield in temperate cereals. Crop Sci. 42:111-121.

SAS Institute. 1999. SAS OnlineDoc ${ }^{\circledR}$, Version 8. SAS Institute Inc., Cary, North Carolina, USA.

Shakhatreh, Y., O. Kafawin, S. Ceccarelli, and H. Saoub. 2001. Selection of barley lines for drought tolerance in low-rainfall areas. J. Agron. \& Crop Sci. 186:119127.

Talamè, V., M. Sanguineti, E. Chiapparino, H. Bahri, M. Salem, B. Forster, et al. 2004. Identification of Hordeum spontaneum QTL alleles improving field performance of barley grown under rainfed conditions. Ann. Appl. Biol. 144:309-319.

Thomas, W. 2002. Molecular marker-assisted versus conventional selection in barley breeding. p. 177-203. In G. Slafer et al. (eds.). Barley science. Recent advances from molecular biology to agronomy of yield and quality. Food Products Press, New York, USA.

Zadoks, J.C., T.T. Chang, and C.F. Konzak. 1974. A decimal code for the growth stages of cereals. Weed Research 14:415-421. 